\title{
貴金属リサイクルを取り巻く現状と課題
}

\author{
萱沼 義弘 ${ }^{1} \quad$ 水 橋 正 英 ${ }^{2} \quad$ 新藤裕一朗 1 \\ 1松田産業株式会社生産統括本部技術開発部 \\ 2松田産業株式会社貴金属材料事業部化学品部開発課
}

J. Japan Inst. Met. Mater. Vol. 81, No. 4 (2017), pp. 152-156 Special Issue on Frontier of Recycling Technology for Precious Metals (C) 2017 The Japan Institute of Metals and Materials OVERVIEW

\section{The Present State and Problems of Precious Metals Recycling}

Yoshihiro Kayanuma ${ }^{1}$, Shoei Mizuhashi ${ }^{2}$ and Yuichiro Shindo ${ }^{1}$

${ }^{1}$ Technical Development Dept., Production Control Division, MATSUDA SANGYO CO.LTD., Iruma 358-0034

${ }^{2}$ Research and Development Sect., Chemical Products Dept., Precious Metal Division, MATSUDA SANGYO CO.LTD., Iruma 358-0034

Recycling of precious metals from scraps generated from manufacturing process have been widely done. The recycling process calls for maintenance of confidentiality of the scrap, use of isolated lots for the recycling operation, high recovery rates, short operation time and low treatment costs. In recent years, the recycling process has been facing three additional problems. The first is the reduction in the precious metal content in the scraps because of their substitution by other non-ferrous metals. The second is the contamination of metals that are never contained in natural ores. They have been used for upgrading the product performance, but those contaminations make it difficult to extract and purify precious metals. The third is the enforcement of stringent environmental regulations in Japan, which prohibits the continuous use of certain chemicals such as nitric acid. This paper describes the work carried out by a precious metals recycling company to solve the aforementioned problems.

[doi:10.2320/jinstmet.JE201603]

(Received October 4, 2016; Accepted November 24, 2016; Published January 16, 2017)

Keywords: precious metals, recycling, scraps

1. 緒言

貴金属は, その特異な物理的・化学的性質から, 社会の 様々な分野で用いられている。最も普遍的なのは, その希少 性や独特の光沢から「価值」を表象するものとしての宝飾品や 貨幣などであり，世界中のほとんどの国で流通している。一 方, その耐食性, 電気伝導性といった特徵から, 産業分野で も幅広く使われている. 金 $(\mathrm{Au})$, 銀 $(\mathrm{Ag})$ は電気の良導体であ り, 銅 $(\mathrm{Cu})$ などに比べ酸化や腐食に強いことから, 電子部 品・半導体分野で使われている. 白金 $(\mathrm{Pt})$, パラジウム $(\mathrm{Pd})$, ロジウム $(\mathrm{Rh})$ は, 融点が高く耐熱性がある, 特異な触媒性能 を示す, 酸化や腐食に強いといった特徵から, 自動車排ガス 浄化触媒, 石油化学合成触媒などに用いられている。一般的 に貴金属は, 他の金属と比べ重量当たりの単価が高いことか ら，産業界においても貴金属を他の金属で置き換える試みを 行ってきたが，一部を除いては未だ代替が効かず，今後も貴 金属は産業分野で幅広く使われていくと予想される.

近年, 資源価格の乱高下や，金属資源を鉱山から採取する 際の環境破壞の大きさが問題となり, 安定調達と環境保護の 観点から, 使用済み製品より金属などをリサイクルする動き が進められている.リサイクルが進むための誘因の一つは経 済合理性であり，使用済み製品に単価の高い金属が含まれる 場合は，それを回収し売却すれば，リサイクルにかかる費用
を差し引いても利益が得られることから, 積極的に進められ る. その意味で, 重量当り単価が他の金属に比べて高い貴金 属を含む使用済み製品のリサイクルは，積極的に行われてき た. 具体的には, 写真感材フィルム $(\mathrm{Ag})$, 写真現像・定着液 $(\mathrm{Ag})$, プリント実装基板など使用済み電気・電子製品 $(\mathrm{Au}$, $\mathrm{Ag}, \mathrm{Pd})$, 自動車排ガス処理触媒 $(\mathrm{Pt}, \mathrm{Pd}, \mathrm{Rh})$ などである.

また, これとは別に, パソコンや携帯電話など電気・電子 製品を構成するプリント基板，コネク夕，集積回路，コンデ ンサといった部品や部材を製造する工場では, 何らかの工 ラーにより製品機能が仕様に満たない廃棄品が発生する。本 稿ではそれを「工程スクラップ(process scrap)」と呼ぶ. この 工程スクラップにも貴金属が含まれる。また，金属板から部 材を打ち抜いた後の残材, 貴金属めっきを行った後のめっき 廃液, 石油化学合成プラントから発生する使用済み触媒など, 製品を製造する過程で用いられる部材や廃棄物にも, 貴金属 が含まれる場合がある。製造メーカーにとっては，工程スク ラップや廃液・廃材に含まれる貴金属は貴重な資産であり, 回収・再利用が求められる。そうした要望に応えるため, 貴 金属の回収・精製を行うことを業とする貴金属回収製錬業者 が古くから存在してきた，大きく分けると，銅や亜鉛など鉱 石の製鍊を祖業とし，それらのプロセスを生かして貴金属を 回収する鉱山系のリサイクル業者と, 貴金属やそれに付随す る有価金属の取扱いに特化した回収製錬業者とがある。前者 は鉱山運営で培った乾式製錬とそれに続く分離精製プロセス 
を主体に，後者は湿式製錬を主体にしている場合が多く，松 田産業は後者に属する．貴金属リサイクルについては，これ までに優れた総説が数多く報告されているので1-4), 本稿で屋 上屋を重ねることにならないようにしたい，ここでは，貴金 属のリサイクルを取り巻く状況と課題について, 主に工程ス クラップからの貴金属回収に的を絞り, 回収製錬業者の視点 から考察した内容について概説する.

\section{2. 貴金属リサイクルの現状}

\section{1 松田産業における貴金属リサイクル}

松田産業は, 加工食品の原材料の輸入 - 卸売, 貴金属の回 収・リサイクル，産業廃棄物の適正処理を柱として事業展開 する，他にあまり類を見ない会社である．本稿ではこれらの 事業のうち，貴金属の回収・リサイクルについて述べる．当 社では貴金属 8 元素のうち, $\mathrm{Au}, \mathrm{Ag}, \mathrm{Pt}, \mathrm{Pd}, \mathrm{Rh}$ を中心 リサイクルを行っている。 また，東アジア各地に展開してい る電子部品・半導体工場から発生する工程スクラップを回収 するため, アジア各地に現地法人を設立し, 一部の拠点では 製錬・精製機能を保有している。 そのため, 工程スクラップ を日本に送らずとも, 現地での回収製錬対応が可能である. また，要望があれば，製造メーカーの工程に回収装置を設置 し, 貴金属を回収するサービスも行っている ${ }^{5)}$. 産業廃棄物 処理事業では，47都道府県での収集・運搬許認可を保有し， 各地の委託処理会社と協力して, 製造メーカーから発生する 廃液・廃棄物の無害化処理・リサイクルを行っている ${ }^{6)}$. 自 社の貴金属製錬工程から発生する廃液も無害化処理を行って いる．特に，写真廃液の海洋投棄が1995年に禁止された際に 導入した高温酸化反応装置は, 液中燃燒法を採用して高 BOD の写真廃液を分解・無害化する, 日本で初めての設備であっ た.

\section{2 工程スクラップからの貴金属リサイクルの特徵}

ここでは，工程スクラップからの貴金属リサイクルにおけ る特徵について述べる. Fig. 1 に, 資源循環の代表的な構図 を示す。これは, 南條により提案された資源のリサイクル チェーンを基にしており, 基本的な原理は変わらないが, 工 程スクラップに関する部分を右側に抜き出し, スクラップの 処理委託契約, 前処理・サンプリング, 分析, 回収製錬を経 て再生資源 (Recycled materials)に至る流れを明示したもので ある7). 工程スクラップリサイクルの特徽は大きく分けると 「機密保持」「個別処理 - 鉱量決定」「回収率 ・ 納期 ・ コスト」と なる。

\subsection{1 機密保持}

工程スクラップは, 廃棄品とはいえ製造メーカーの製品の 仕掛品であることから, 素材の種類や設計などの機密情報が 含まれている場合が多い. 製造メーカーとしては, 当然, こ れらの情報を外部に漏らすことなく貴金属をリサイクルした いと考える. そうした要望に応えるため, 回収製錬業者にお ける機密保持体制の構築は必須である. 具体的には, 工程ス クラップを引き取った後の回収製錬業者の工場からの流出防 止, 工程スクラップを粉砕することなどによる製品設計・機
能情報の流出防止などである.

松田産業では, 製造メーカーからの機密保持要求に対応す るための様々な体制を採っている. 工程スクラップが当社工 場に入庫してから外部に持ち出されることの無いように, 監 視カメラ, 24 時間有人監視, 工場退出時の $\mathrm{X}$ 線検査などのセ キュリティ体制を構築し運用している．また，製造メーカー の要望があれば, 当社工場内に先方の担当者を招き, 担当者 の目の前で開梱して工程スクラップを確認した上で破砕・焼 成・酸溶解を行い機能破壊を証明する, いわゆる「立会い処 理」にも対応している. さらには, 製造メーカーの工場から外 部に搬出する前に機密情報を破壊したいという要望を頂く場 合もあるので, トラックの荷台部分に破砕機・集塵機などを 設置した移動式粉砕車を常備しており, 要請があれば製造 メーカーの工場に赴いて先方の構内で破砕し, 機密滅却する 対応も行っている. Fig. 2 に移動式粉砕車の外観を示す.

\section{2 .2 個別処理 ・ 鉱量決定}

製造メーカーからは, 自社の工程スクラップを単独で処理 し，その中に含まれる貴金属量をできるだけ正確に把握した いと要望される場合が多い. 製造メーカーから搬出される工 程スクラップの 1 ロット当りの量は, 数 $\mathrm{kg}$ もあれば数百 $\mathrm{kg}$ もあるなど一様ではなく, そこに含まれる貴金属も, $\mathrm{Au} の$ み, $\mathrm{Au} \cdot \mathrm{Ag} \cdot \mathrm{Pd}$ 含有, など様々なケースがある. ロットの 大きさや構成は製造メーカーが決めるものであり, 回収製錬 業者は, それらを個別に処理するニーズに応えるための体制 を採っていかねばならない，松田産業では，湿式製錬におい

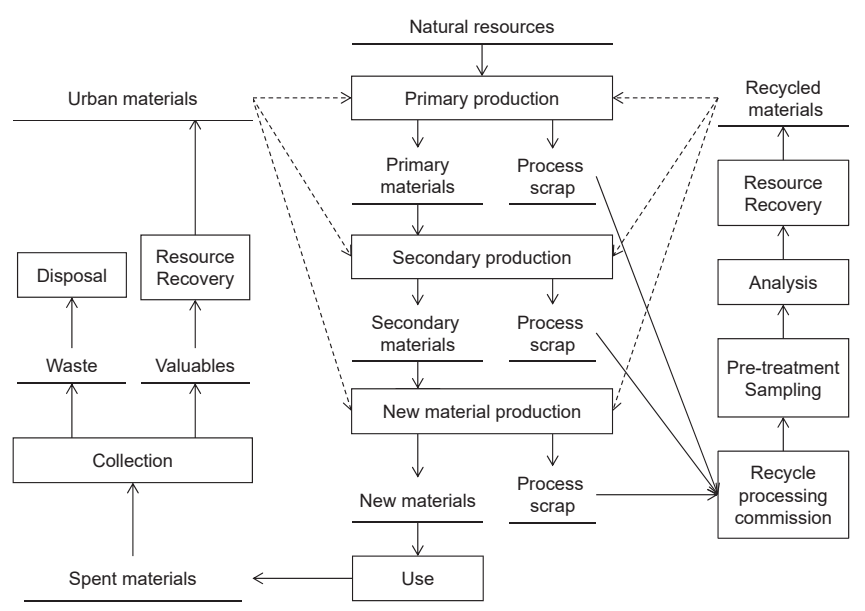

Fig. 1 Schematic diagram of recycling from process scrap.

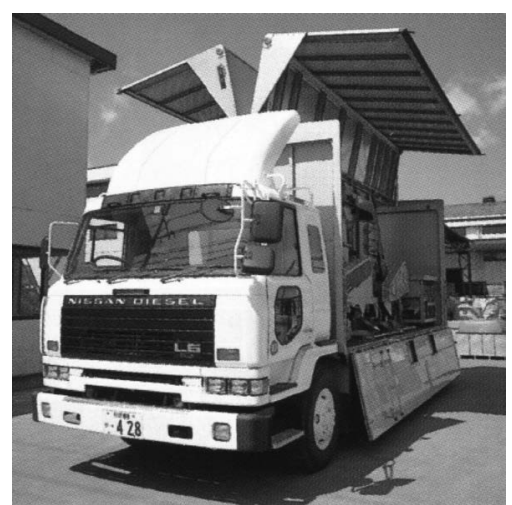

Fig. 2 Mobile crusher machine. 
て工程スクラップの量に応じた溶解槽を用意し，個別処理に 対応している.

また，工程スクラップ中の貴金属量を決定する分析手法も 重要である. 貴金属は高価であることから, 分析值が数 $\mathrm{mg} \cdot \mathrm{dm}^{-3}$ 変わっただけでその工程スクラップの評価額が大幅 に変わることも起こり得る．鉱石中の貴金属含有量分析法は JIS に公定法があるが，工程スクラップは種々雑多であり決 まった分析法がない，そのため, 通常は製造メーカーと回収 製錬業者の間で分析方法に関するすり合わせがなされ，互い が了解した方法で分析している. 回収製錬業者がサンプリン グした分析サンプルを製造メーカーに渡し，先方でも分析し て双方で結果を突き合わせることもある．製造メーカーに納 得してもらえるだけの分析技術・体制を整えることが重要で ある。

工程スクラップの分析方法は，そこに含まれる貴金属の濃 度や物量によって変わる，高品位のスクラップには精度の高 い分析法が要求され，重量法といった手法が採られる．低品 位のスクラップは, 酸やアルカリに溶解して原子吸光分析や 高周波誘導結合プラズマ発光分光分析 (ICP-AES)などの機器 分析で鉱量決定する場合が多い. 低品位で量も多いときは, 粉砕・混合を行い均質化した上でサンプリングし，そのサン プルの分析值を採用する．工程スクラップに含まれる貴金属 の種類, 共存する金属元素やプラスチックなどの成分と量, 全体の物量などを見極めた上で，どのように分析すれば必要 な精確さの分析值を出せるか判断する．精確さを重視するあ まり過㮃なまでの分析を行うと，コストが膨大になり，業と して立ち行かなくなる。排出元である製造メーカーの要望を 汲んだ上で，最適な鉱量決定方法を採用することが重要であ る.

\subsection{3 回収率・納期・コスト}

製造メーカーは当然のことながら，分析值から計算される 貴金属量を可能な限り多く, 早く, 安く回収したいという要 望を持っている。 工程スクラップからの貴金属回収で重視さ れるのは, この「回収率」「納期」「コスト」の 3 点である. 回収 製錬業者はこの 3 点に関し顧客の要望に応えるため, 日夜努 力を続けている.

回収率を上げるためには，貴金属と不純物，あるいは貴金 属同士の分離精製における収率を上げること，また，廃液等 に漏洩した貴金属を回収しロスを減らすことが大切である. 収率を上げるには工程の反応条件を適切に保つことが必要で あり, 作業標準による管理徹底, あるいは機械による自動化 で人に起因する反応操作のブレをなくす，といった対応を 採っている，ロスの削減には，廃液を送液するラインにイオ ン交換樹脂や活性炭による吸着塔を設置するといった対策を 行っている。

納期短縮については，技術的な側面もさることながら，工 程の運用・管理が重要である。ひとつの反応槽に多数のロッ トが集中してしまうと, その工程が律速段階になって全体の 処理が滞り, 納期遅延に繋がる. 各工程にかかる負荷を平準 化し納期短縮を進めるために，当社では工程管理システムを 導入して専門部署が全体を管理する体制を採っている。また， ひとつの工程を多数の社員が運用できるような多能工化を進
めており，担当者がいないからその工程が動かない，といっ た事態を回避している.

コスト削減においては, 補助材料の集中購買といった日常 の改善活動は当然行っているが, 顧客のコストダウン要求は 年々厳しくなり, 抜本的なコスト構造改革の必要性も感じて いる．貴金属回収で特に費用がかかるのは，例えば工程スク ラップ中の有機成分を除去するための焼成費，回収製錬後の 廃液・排ガス処理費，人件費といったところである．当社に おいても焼成費用を抑えるための事前分別, 廃液の再利用, 人件費削減のための機械化・自動化といった施策を検討して いる. 金属濃度や酸濃度の薄い廃液をスクラップ溶解の希釈 水として再利用するなど, 少しずつ効果が現れている.

\section{3. 貴金属リサイクルを取り巻く課題}

貴金属の回収製錬業者にとっての事業上の課題やリスクと しては，これまでは貴金属相場の乱高下が主なものであった. しかし近年, 新たな問題が現れてきており, 事業継続にも係 る重要な課題と位置付けている. 以下の項でその概略を述べ る.

\section{1 省金化}

近年，製品のコストダウンを進めるため，貴金属など高価 な金属を使用しない，あるいは他の低価格金属で代替すると いった動きが進んでいる，希少資源の有効利用としては良い 傾向であるが, 回収製錬業者にとっては新たな事業リスクに なりかねない面もある。回収製錬業者は工程スクラップから の貴金属回収において，スクラップの物量に比例する製錬費， 並びに貴金属量に比例する精製費を頂いている．工程スク ラップ中の貴金属量が減るということは，すなわちこの精製 費が減るということになり, 回収製錬業者の収入減に繋がる. 工程スクラップ中の貴金属量があまりに少なくなった場合は 回収製錬業者の採算が取れなくなり，「有償で買う」対象から 「費用を払って処理する」対象になりかねない.

こうした省金化の兆候は徐々に現れてきている．Fig. 3 は 当社が定期的に引き取っているある実装基板の $\mathrm{Au}$ 品位の経 年変化を追ったものである. 2011年 1 月の Au 品位を100とし た相対值で表わしている，全体的な傾向としては右下がりで ある.これは実装されている電子部品の小型化に伴う $\mathrm{Au}$ 使 用量減少，また， $\mathrm{Au}$ を使っていた部分の他金属への代替と いった影響が現れているものと推察される．Au以外の金属へ の代替の一例としては, IC のボンディングワイヤが挙げられ る. 従来ICチップとリードフレームの接続には, Auボンディ ングワイヤが用いられていた. IC パッケージの小型化ととも に, その径も $15 \mu \mathrm{m}$ 程度まで細線化され, IC 個数当りの $\mathrm{Au}$ 使用量は減少傾向にあった。しかし近年, $\mathrm{Au}$ の代わりに $\mathrm{Cu}$ を用いた $\mathrm{Cu}$ ボンディングワイヤが開発され，Au そのものを 使用しない流れとなってきた ${ }^{8)} . \mathrm{Cu}$ ボンディングワイヤの開 発は IC の低価格化や高性能化に繋がる有用な発明であり, こ うした傾向は今後ますます加速すると予想される。リサイク ルでの採算性を考える上で，回収製錬業者は，こうした動向 に対応する新しい収益の形を模索しなければならない. 


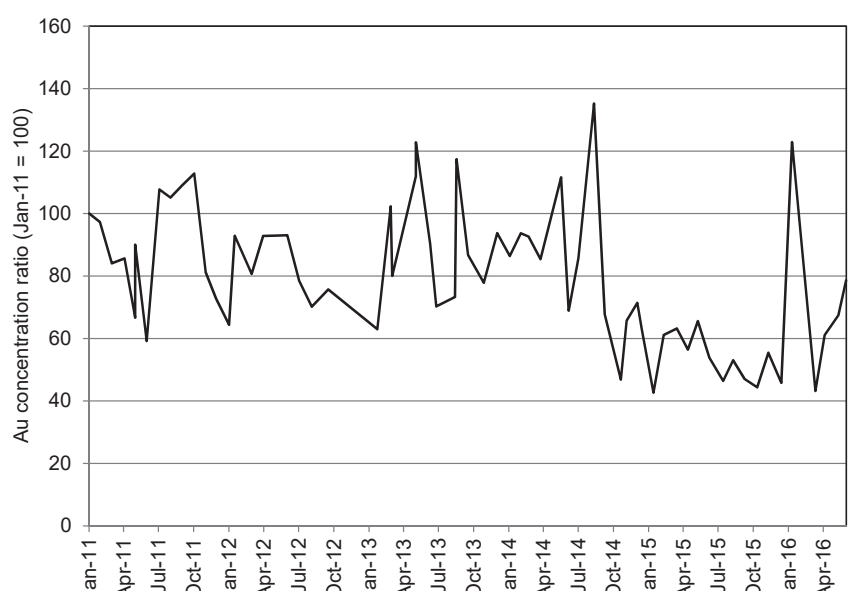

Fig. 3 Example of the trends of Au concentration in print circuit board scraps.

(Au concentration of Jan-11 $=100$ as an index.)

\section{2 複雑化}

製品の機能向上の観点から, メーカーは部品に使用する金 属を様々に組み合わせ，独自の機能を発現させている，そう した製品の工程スクラップが回収製錬業者に供給された際に は，新たな問題が起きる可能性がある，通常，貴金属と不純 物の分離，または貴金属同士の相互分離では，例えば導電 ペーストは $\mathrm{Ag}$ と $\mathrm{Pd}$ が主体というように，概ね元素の組合せ は決まっている。回収製錬業者は, そうした代表的な工程ス クラップに適したプロセスを採用し業を営んできた。しかし, 製品技術の進歩によってある時期から突然それまでに含まれ ていなかった別の元素が加わると, 既存プロセスでは回収製 錬できなくなる場合もある. 競争上, 回収製錬業者はそうし たスクラップにも対処せねばならないが，通常より手間やコ ストがかかることが多い.

ハードディスク $(\mathrm{HD})$ の磁気記録媒体の例を挙げる. 垂直磁 気記録方式による HD を採用したハードディスクドライブが 出回り始めた頃は, 磁性層の構成は $\mathrm{Co}-\mathrm{Cr}-\mathrm{Pt}$ が主体であっ た. HD の製造プロセスから発生する工程スクラップや製造 部品からの回収対象も, Ptのみであった. しかしその後, 磁 性膜の結晶下地層に Ru を用いる構造が普及した ${ }^{9)}$ 。これに伴 い, HD 製造プロセスから発生する工程スクラップに Ru が含 まれるようになった. Pt と Ru は同じ白金族金属(PGMs)で, 通常の Pt 精製プロセスに Ru が混入すると分離精製の過程で 同様な化学的挙動を示すため, Ptの最終製品にまで残って ロットアウトを引き起こすことがある．Ruの分離方法として は四酸化ルテニウム $\left(\mathrm{RuO}_{4}\right)$ まで酸化させて揮発分離する蒸留 法が知られている。これを適用すれば基本的には Ruを分離 できるが，そのためには塩素など強力な酸化剂を使用せねば ならない. 既存プロセスが塩素に対応していなければ, 相応 の設備導入の必要が出てくる. しかし, そのようなコストを かけて Ru を回収しても, 現状の $\mathrm{Ru}$ 相場は $\mathrm{Au}$ や Pt に比べる と一桁低く, 物量も少ないためほとんど採算に合わない.こ うした事例が増えてくると，回収製錬業者にとっては事業継 続上の新たな脅威となる。対処法としては, 混入した不純物 元素を容易に排除できるプロセス，あるいはPGMs の分離選
択性の高いプロセスの構築が挙げられる. 旧来の沈殿・晶析 法では PGMs の選択性をさらに上げることは困難であり, 溶 媒抽出法や, 貴金属イオンの選択性を高めたイオン交換樹脂 法の研究が行われている1,4,10,11). 当社においても様々な分離 精製方法を調査検討しており, 先に述べた Ruに関しては, 既 存プロセスに酸化剂を投入し揮発分離させている。しかし, コストの増加や揮散した $\mathrm{Ru}$ の回収といった課題が残ってお り, 更なる改善が必要である。

\section{3 環境規制}

環境規制への対応は事業継続上の重要な課題であり, 当社 も ISO14001を取得し, 環境マネジメントを実施している。だ が, プロセスの原理上，一朝一夕に工程を変えることができ ず，業界として行政に猶予期間をもらいながら解決に向けた 努力を続けている項目もある。貴金属リサイクルでの代表的 なものが窒素規制である，貴金属の湿式製錬では，窒素を含 有する様々な化合物が用いられている，例えば，古来より貴 金属の溶解には王水が用いられてきたが, これは体積比で硝 酸 1 : 塩酸 3 〜 を合わせた混酸である.これを用いると $\mathrm{Au}$, $\mathrm{Pt}, \mathrm{Pd}$ を下記の反応式のように溶解することができる。ま た, $\mathrm{Ag}$ は塩化物イオンが存在すると不溶性の $\mathrm{AgCl}$ になるた め, 硝酸のみで溶解する.

$$
\begin{gathered}
\mathrm{Au}+\mathrm{HNO}_{3}+4 \mathrm{HCl} \rightarrow \mathrm{H}\left[\mathrm{AuCl}_{4}\right]+\mathrm{NO}+2 \mathrm{H}_{2} \mathrm{O} \\
3 \mathrm{Pt}+4 \mathrm{HNO}_{3}+18 \mathrm{HCl} \rightarrow 3 \mathrm{H}_{2}\left[\mathrm{PtCl}_{6}\right]+4 \mathrm{NO}+8 \mathrm{H}_{2} \mathrm{O} \\
3 \mathrm{Pd}+4 \mathrm{HNO}_{3}+18 \mathrm{HCl} \rightarrow 3 \mathrm{H}_{2}\left[\mathrm{PdCl}_{6}\right]+4 \mathrm{NO}+8 \mathrm{H}_{2} \mathrm{O} \\
3 \mathrm{Ag}+4 \mathrm{HNO}_{3} \rightarrow 3 \mathrm{AgNO}_{3}+\mathrm{NO}+2 \mathrm{H}_{2} \mathrm{O}
\end{gathered}
$$

調合が容易で $\mathrm{Au}, \mathrm{Pt}, \mathrm{Pd}$ を迅速に溶解することから, 王水 は貴金属製錬では長く用いられてきた。しかし, その組成が 示すように硝酸を必ず用いねばならず，王水を使用する限り 硝酸態窒素の問題は避けられない. また, 旧来の精製法であ る晶析・沈降分離では, Pt P Pd の精製でアンモニア態窒素 が用いられる。

$$
\begin{gathered}
\mathrm{H}_{2}\left[\mathrm{PtCl}_{6}\right]+2 \mathrm{NH}_{4} \mathrm{Cl} \rightarrow\left(\mathrm{NH}_{4}\right)_{2}\left[\mathrm{PtCl}_{6}\right] \downarrow+2 \mathrm{HCl} \\
\mathrm{H}_{2}\left[\mathrm{PdCl}_{6}\right]+2 \mathrm{NH}_{4} \mathrm{Cl} \rightarrow\left(\mathrm{NH}_{4}\right)_{2}\left[\mathrm{PdCl}_{6}\right] \downarrow+2 \mathrm{HCl}
\end{gathered}
$$
水質污濁防止法における「アンモニア, アンモニウム化合物, 亜硝酸化合物および硝酸化合物」の暫定排水基準として，貴金 属製錬業者が含まれる「貴金属製造・再生業」には，2016年 6 月の省令改正で $2,900 \mathrm{mg} \cdot \mathrm{dm}^{-3}$ が適用された。 しかしこれは あくまで暫定措置であるため, できるだけ早期の解決が求め られている.

窒素規制への対応策としては，(a) 窒素成分の分解，（b)硝 酸を使わない貴金属の溶解，が考えられる。（a）については, 一般的には微生物による硝酸態窒素やアンモニア態窒素の処 理が挙げられる ${ }^{12)}$ 。これは, 窒素成分を含む廃液を微生物の 生育に適した状態に調整し, 栄養塩を添加して微生物に硝酸 やアンモニアを分解させる方法である13,14). 当社でも検討を 進め, 窒素成分の分解条件を見出すことはできている. しか し，元々の廃液中の塩濃度が高いため, 微生物が生育するた めには $3 \sim 4$ 倍の希釈が必要となり廃液量が増大すること, 微生物が環境变化に弱いため, 温度を一定に保ったり栄養塩 を定期的に添加したりするなど管理に手間とコストがかかる ことなどから，実用に至っていない，一方，当社独自の施策 
Table 1 Results of the non-catalytic reduction of waste water containing nitrate ion.

\begin{tabular}{ccccc}
\hline No. & $\begin{array}{c}\text { Initial concentration of } \\
\text { nitrate ion in waste } \\
\text { water, } \\
C_{\text {in }} / \mathrm{mg} \cdot \mathrm{dm}^{-3}\end{array}$ & $\begin{array}{c}\text { Ingection rate of } \\
\text { waste water, } \\
D_{\text {NO3- }} / \mathrm{kg}^{-1} \mathrm{~h}^{-1}\end{array}$ & $\begin{array}{c}\text { Ingection rate of } 28 \mathrm{vol} \% \\
\text { ammonium solution, } \\
D_{\mathrm{NH}+} / \mathrm{dm}^{3} \cdot \mathrm{h}^{-1}\end{array}$ & $\begin{array}{c}\text { Concentration of nitrate } \\
\text { ion after the reaction, } \\
C_{\text {end }} / \mathrm{mg}^{-1} \cdot \mathrm{dm}^{-3}\end{array}$ \\
\hline 1 & 6,700 & 1,100 & 40 & $<10$ \\
2 & 7,400 & 1,100 & 40 & $<10$ \\
3 & 8,000 & 1,100 & 55 & 15 \\
4 & 5,500 & 1,090 & 55 & 13 \\
5 & 3,000 & 1,100 & 40 & $<10$ \\
\hline
\end{tabular}

として, 写真廃液処理の高温酸化反応装置を用いる方法があ る. 同装置は $900^{\circ} \mathrm{C} て ゙$ 廃液を処理する工程があり, そこに硝酸 廃液とアンモニア廃液を適切な混合比で噴霧すると, 無触媒 脱硝反応により硝酸とアンモニアが窒素まで分解される ${ }^{14)}$. 反応式は次のように推定されている.

$$
4 \mathrm{NO}+4 \mathrm{NH}_{3}+\mathrm{O}_{2} \rightarrow 4 \mathrm{~N}_{2}+6 \mathrm{H}_{2} \mathrm{O}
$$

写真廃液には錯形成や $\mathrm{pH}$ 調整のためアンモニウムイオンが 含まれており, 硝酸態窒素分解のためのアンモニア成分が予 め含まれていると見ることもできる。本法の適用を見込み, 硝酸態窒素を含有する廃液を高温酸化反応装置で処理した結 果例を Table 1 に示す。 このときはアンモニア成分の不足が 懸念されたため, 別途アンモニア水溶液を添加している. 投 入前に総窒素量 $(\mathrm{T}-\mathrm{N})$ として $3,000 〜 8,000 \mathrm{mg} \cdot \mathrm{dm}^{-3}$ あった硝 酸態窒素が高温酸化処理後に $15 \mathrm{mg} \cdot \mathrm{dm}^{-3}$ 以下となるなど，良 好な結果が得られた，その後も試験を重ねて窒素含有廃液の 適切な処理条件を確立し，現状では高濃度硝酸廃液は概ね高 温酸化装置を使って処理している。ただし，本法には処理コ ストが高いという問題点がある。当面の窒素規制対応として 使用するが永続的に使うことは事業上困難であり, 次に述べ る新規溶解方法の確立など新たな施策が求められている.

(b)については, 当社でも塩素や過酸化水素を用いた試験 を行ったが，貴金属の溶解スピードや取り扱いの簡便さから 実用的に王水に勝る溶解方法を見つけられていない. しかし 外部に目を向けると, ここ10年ほどの間, 溶解する媒体の工 夫ではなく溶かされる側の貴金属に処理を施し, 易溶化させ る研究が進展している，筆者も10年ほど前に前田, 岡部らと ともに PGMs に活性金属を作用させて酸に易溶化させる方法 を検討し, $\mathrm{Mg}$ やCaを用いて効果を上げることができた ${ }^{15-18)}$. この方法はその後, 前田や岡部によりさらに研究が進められ ている ${ }^{19,20)}$.また, Ptや Pd とアルカリ金属酸化物を作用さ せ, 複合酸化物として酸への溶解性を改善する方法も研究さ れている ${ }^{21,22)}$.こうした研究が実用化に結びつくことで, 窒 素規制の問題が解決される可能性もある.

\section{4.おわりに}

近年は「都市鉱山」として，使用済み製品に含まれる貴重な 金属類を有効利用するための取り組みが数多く行われている.
これらは，そのままでは廃棄されてしまう金属類を再び資源 循環のループに乗せる試みであり, 日本の資源安全保障上重 要な施策と言える。 そうした中, 工程スクラップからの貴金 属回収は，すでに経済原理に則って金属資源循環がなされて いる一例と見ることができるが，近年になり顕在化してきた 省金化・複雑化・環境規制といった問題はそうした循環を頓 挫させてしまう可能性を秘めている. この難題を解決し, 産 業界における持続可能な貴金属利用を実現できるよう, 貴金 属の資源循環を担う一員として貢献していきたい.

\section{文献}

1) J. Shibata and A. Okuda: Shigen-to-Sozai 118(2002) 1-8.

2) T. H. Okabe, H. Nakada and K. Morita: J. Surf. Sci. Soc. Japan 29 (2008) 592-600.

3) T. H. Okabe and K. Nose: Mater. Cycles. Waste Manag. Res. 22 (2011) 50-57.

4) A. Okuda and S. Shioda: J. Surf. Finish. Soc. Jpn. 53(2002) 647651.

5) S. Mizuhashi and T. Honda: J. Surf. Finish. Soc. Jpn. 66(2015) 81-85.

6) T. Tachikawa: Indust 31(2016) 16-20.

7) M. Nanjo: Bulletin of the Research Institute of Mineral Dressing and Metallurgy, Tohoku University 43(1988) 239-251.

8) T. Uno, S. Terashima and K. Kimura: Materia Japan 50 (2011) 30-32.

9) Y. Miura: Materia Japan 46(2007) 180-183.

10) J. Shibata: J. Surf. Finish. Soc. Jpn. 53(2002) 641-646.

11) H. Narita and M. Tanaka: J. MMIJ 127(2011) $175-181$.

12) S. Takizawa: J. Env. Conserv. Eng. 30 (2001) 902-906.

13) T. Hoshino, H. Hirosawa, T. Matsukawa,T. Ogawa, Y. Ejiri, S. Tsuneda and A. Hirata: Journal Japan Biological Society of Water and Waste 40 (2004) 137-142.

14) Y. Kinoshita: Japan J. Water Pollution Research 12(1989) 79-86.

15) T. H. Okabe, S. Yamamoto, Y. Kayanuma and M. Maeda: J. Mater. Res. 18(2003) 1960-1967.

16) T. H. Okabe, Y. Kayanuma, S. Yamamoto and M. Maeda: Mater. Trans. (JIM) 44(2003) 1386-1393.

17) Y. Kayanuma, T. H. Okabe, Y. Mitsuda and M. Maeda: J. Alloy. Compd. 365(2004) 211-220.

18) Y. Kayanuma, T. H. Okabe and M. Maeda: Metall. Mater. Trans. B 35B (2004) 817-824.

19) H. Sasaki and M. Maeda: J. Japan Inst. Met. Mater. 75(2011) 602-606.

20) C. Horike, K. Morita and T. H. Okabe: Metal. Mater. Trans. B 43B (2012) 1300-1307.

21) R. Kasuya, T. Miki and Y. Tai: J. Ceram. Soc. Jpn. 121 (2013) 261-264.

22) R. Kasuya, T. Miki, H. Morikawa and Y. Tai: Metal. Mater. Trans. B 46(2015) 2476-2483. 